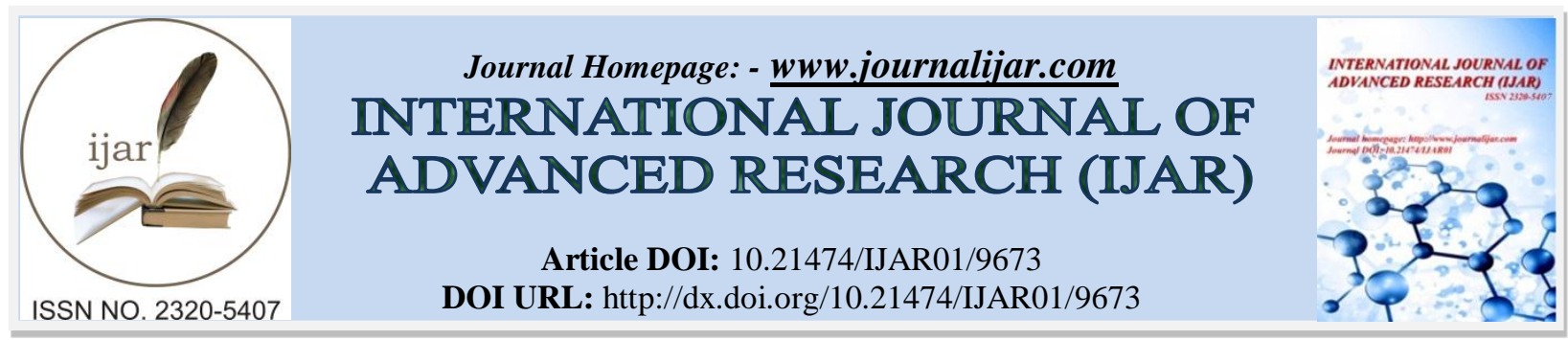

RESEARCH ARTICLE

\title{
ISSUES AND TRENDS IN THE GROWTH AND DEVELOPMENT OF CHRISTIANITY IN NIGERIA.
}

Jaja Bethel Onyechere.

Ph.d. Fsr, Jplecturer Department Of Religious And Cultural Studies Faculty Of Humanities University Of Port Harcourt.

\section{Manuscript Info}

Manuscript History

Received: 06 July 2019

Final Accepted: 08 August 2019

Published: September 2019

\begin{abstract}
This paper on the Issues and trends in the growth and development of Christianity in Nigeria examined the various waves of development from their inception till our contemporary time. The emphasis of the Pentecostals has been to make the New Testament the blue print of what happened in every generation of Christianity.

Hence they evolved strategies to attract their followers. These are the possible reasons why their major activities are centered on contextualization of their liturgy, communal participate, working of power and deliverance and many others. Our findings shoe that in recent times the activities are been imitated by the mainline churches. This is rather an encouragement to the Pentecostal movement. That all hands should be on deck to have a well-established entrepreneurship for the benefit of the poor.
\end{abstract}

Copy Right, IJAR, 2019,. All rights reserved.

\section{Introduction:-}

Pentecostal/ Charismatic Christianity is thriving in all shapes and sizes across the sub-Sahara Africa. A major side attraction to Pentecostalism is the manifestation of the kind of faith, in which the supernatural is daily observed. This event singularly is sweeping through the continent.

Another major factor in the growth of Pentecostalism is that it is being propagated by Africana and not the foreign missionaries (Tomalin, 2015)

Pentecostalism in its actual sense should be understood as experiential Christianity. This experience eventually leads to the Baptism of the believer in the Holy Spirit; which evidence is by speaking in tongues. In the words of Bruner (1970:21), this experience is exhibited both privately and in the public with other gifts manifesting equally. The general concept of Pentecostals is that the New Testament record ought to be a blueprint of what should happen in every generation of the Christian life until the end of time.

Pentecostals see their practice as a remarkable spiritual manifestation which every Christian today should continue to live in and grow in it.

In a similar vein, the Charismatic movement is the offspring of Pentecostalism. It is mostly said that if there had not been Pentecostalism, probably, there would have been no Charismatic Movement. That is why the Charismatic Movement is said to be a second wave of spiritual revival after Pentecostalism (Culpepper 1977:51). Furthermore, it

Corresponding Author:-Jaja Bethel Onyechere.

Address:-Ph.d. Fsr, Jplecturer Department Of Religious And Cultural Studies Faculty Of Humanities University Of Port Harcourt. 
appears that there is a strong bond that exists between the two movements. The bond that exists between these does not imply that the two are one and the same thing.

There are common traits between the two, but at the same time there are differences. While the Pentecostals can easily break up to form or establish new Churches, the Charismatic operates within its traditional setup in order to bring about spiritual renewal (Williams 2005b:4). Furthermore, one of the most striking features of the Charismatic movement is the resurgence of a deep unity of spirit across traditions and denominational barriers. Therefore what is happening within the Charismatics is spiritual ecumenism (Williams 2005a: 1)

There are also a number of Para Church organizations that promote the cause of the Charismatic tendencies within the Church community worldwide. These groups operate from outside the established churches. Among these are the Full Gospel Business Men's Fellowship International, which started in America by Demos Shakavian (Moller 1983:23). There are also The Gideon International and Haggai International. Other different International Christian Organizations exist worldwide.

The strength of this paper lies on the third wave of Pentecostalism otherwise called the "signs and wonders movement" and the "vineyard movement". According to Peter Wagner (in Lee 2001: 172) this wave emerged in the eighties of the $20^{\text {th }}$ century. It was centered on supernatural work of the Holy Spirit as being experienced in the churches especially among the Evangelicals, without church members becoming either Pentecostals or charismatics. This group emphasises power evangelism, supernatural healing through tele- Evangelism and mass crusades. (Ukah 2007: 14)

The methodology adopted for this work is purely historical and Sociological narratives.

\section{Spiritual emphasis:}

Pentecostalism is a renewal movement that emphasis the experience of God rather than a show of ecclesiastical life. What is more important about Pentecostalism is not their theology or the ecclesiastical structure, but more importantly is the sense of practical experience of God. This probably is the appropriate reason why Pentecostals are seen as a form of "spirituality", whereas Christian spirituality speaks of the live experience of faith, while theology examines the understanding of God. In Africa the precursors of Pentecostalism were indigenous prophetic figures, many who were persecuted out of historic mission denominations for pursuing spiritualities sometimes scandalously perceived by church authority as belonging to the occult. These include prophets William Wadé Harris of the Gold Coast (Ghana), Garrick Sokari Braide of the Niger Delta, Nigeria, Simon Kimbangu of the Congo, Isaiah Shembe of South Africa and many more others. ( Harvey, 1996 :6-8) At the turn of the nineteenth century these prophets challenged Africans to throw away their traditional resources of supernatural succor and turn toward the living God of the Bible. Many of these revivalistic prophetic campaigns only resulted in independent churches when the prophets had left the scene.

Pentecostalism is a movement of the spirit and spirituality is fundamentally about life in the Holy Spirit. It is also a movement united in its experience of "life in the spirit."

\section{Theology}

The teachings and practices of Pentecostalism show features, promises and problems that distinguish it from that expressed by the mainline churches. Among them are the following; Born Again (salvation), the speaking in tongues which is the Holy Spirit baptism.

Pentecostals teach that salvation can be obtained through faith in Jesus Christ for anyone to inherit eternal life. To be born again is otherwise to accept Jesus Christ as one's personal saviour. Pentecostals make the call to repentance a major issue in their public Preaching where people (sinners) are called upon to come forward and receive Jesus Christ as they surrender their lives to him. This phenomenon is repeated vertically in all their gatherings.

Pentecostals believe that the coming of the spirit brings the ability to perform "signs and wonders" in the name of Jesus Christ which accompanies and authenticate their evangelism. Pentecostals especially in Africa, see the role of healing as good news for the poor and the diseased. These signs and wonders promote the aspiration of the Pentecostal and has led to the rapid growth of Pentecostal Churches in many parts of Africa and the world at large. Evangelists or men of God are seen as the carriers of Gods power to heal the sick and ward off evil spirits. The 
numerous healing repeats on the media help in publicizing Pentecostalism. People all over the world are ready and willing to embrace the gospel that present solutions to or that addresses felt needs, like sickness and the fear of evil spirits.

Furthermore, most Pentecostals have contextualized Christianity in Africa as against the supra-cultural religion of the universal church. According to Hodges; there is no place on earth where if the gospel seed be properly planted that it will not produce an indigenous church. The Holy Spirit can work in one country as well as in another.

\section{Prosperity gospel; also called prosperity Theology}

The situation of extreme poverty in the African context is of great concern to Christianity. It offers an opportunity for investment and harvest, which the Pentecostals have cash on with numerous seeds as its bye- product.

Prosperity gospel in recent times have gained several names to itself, these include; the health and wealth gospel, the gospel of success or seed faith.

According to Wilson prosperity gospel is a religious belief among some Pentecostals, who hold the view that financial blessing and physical well- being are always the will of God for them, and that faith, positive speech and donations to religious causes will increase ones mental wealth (Wilson 2007: 140- 142). In the same vain, prosperity theology sees the Bible as a contract between God and humans; if humans have faith in God, He will deliver, secure and prosperity His people. (Walton 2009:94)

This theology emphasizes the importance of personal empowerment where it stresses that Gods will for all people is to be blessed. It speaks of alleviation of poverty and sickness which are viewed as curses that should be broken by faith. These are believed to be achieved through donations of money, material possessions, etc.

According to Kate Bowler, the prosperity gospel was formed from the intersection of three different ideologies: Pentecostalism, New Thought and" an American gospel of Pragmatism, individualism and upward mobility". (Bowler 2013:11)This “American gospel” was best exemplified by Andrew Carnegie's gospel of wealth and Russell Conwell's famous sermon "Acres of Diamond" in which Conwell equated poverty with sin and asserted that everyone could become rich through hard work.

The New Though Movement, which emerged in the 1880s was responsible for popularizing the belief in the power of the mind to achieve prosperity. Initially, its main focus was on achieving mental and physical health, but through the teaching of Charles Fillmore on material success became the order of the day. Similarly, it was E.W. Kenyon, a Baptist minister and an adherent of the Higher Life Movement, was credited with the introduction of mind- power teachings into the early Pentecostal movement (Bowler 2013:14-16) after being exposed to Emerson College of Oratory. Thereafter, he wrote about supernatural revelation and positive declarations. This writing influenced leaders of the nascent prosperity movement during the post war American healing revival. (Bowler:20). It was Kenyon teachings that shaped the theology of deliverance and healing evangelism. Then followed by Oral Robert, in 1953 faith healer A. A. Allen who published "The Secret of Scriptural Financial Success and Promoted Merchandise" such as "Miracle Tent Shavings" and prayer cloths anointed with "Miracle oil" (Robins, 2010:35). It was Allen who introduced the teaching on the word of faith or "the power to speak something into being" (Robins: 35). By 1960s, prosperity Gospel became a primary focus in healing revivals and crusaded where prosperity is emphasized. Most of these preachers like T. L. Osborn became ostentatious in their display of wealth, fund- raising tactics where unfairly pressure was mounted on the attendance. Soon, these tactics became prompted in different parts of the developing nationwide radio and television networks, through the emergence of Television Network like TBN, Faith, Daystar etc. Between 2000 and now-prosperity theology has become an acceptable norm among the Neo- Pentecostals Movement, their teachings is most appealing to the impoverished poor in the third world because of its promised economic improvement in their welfare.

Wealth is interpreted in prosperity theology as a blessing from God, obtained through obeying the spiritual laws of positive confession, visualization and donation (Wilson, 2017:141-142). The prosperity theology teaching of positive confession stems from its proponents view of scripture. The Bible is seen as a faith contract between God and Christian believers. God is understood to be faithful and just and will not fail to keep to his contract. Prosperity theology uses positive confessions to advance its purpose. Therefore, when a believer speaks positively by faith, they are bound to receive what already is theirs. The ingredients that are used to support this theology are the following Bible books; Malachi 3: 10 "Bring to the store house a full tenth of what you earn...", Philippians 4:19, 
"My God shall supply all your needs according to His riches in glory by Christ Jesus", 3 John1:2 "Beloved, I wish above all things that you prosper and be in health ....". These are regarded as the key Biblical passages that address poverty issues.

\section{Negative Tendencies within Pentecostalism}

Pentecostalism has brought relief, blessing and healing to many homes. However, attempt is being made here to address what is considered in this paper as the negative side of Pentecostalism.

\section{Superiority:}

Pentecostalism has a predisposition towards elitism built into its theology. The error inherent in this position is as results of the wrongful theological believe that only spirit filled Christians that would be effective in winning the world before the return of Christ. According to Parker (1984:183 - 197) this emphasis breeds an inevitable degree of pride within the Pentecostals. Ironically, for a movement that speaks so much of unity but in actual sense creates disunity.

\section{Divergent:}

Pentecostalism is by habit an insular movement whereas; tend to limit their "world" to their own movement, restricting their members to reading, listening and fellowshipping only within the Pentecostal churches. This type of religious isolation has its effect across generations, creating intra- cultural adaptation so that Pentecostalism continues to be a divergent branch of Christianity. This sectarian trend brings with it all the dangers of any cult-like movement. (Parker, 184)

\section{Experience-based}

Pentecostals appeal frequently towards feelings and focusing too often on human and spiritual experiences, this tends to make them more preoccupied with the emotional element of spirituality. Here, experience and personal knowledge is set against theological knowledge. This leads to a culture of ego-focused spirituality with members who increasingly become absorbed by their own individual quests for self-fulfillment through personal encounters with God. It also creates the sub-Christian tendency to rely on, as a basis for faith, personal experiences and group culture. ( parker, 184)

\section{Counter-intellectual}

Pentecostalism often sets the spiritual over against the intellectual, and devalues academic study and argument, which by consequence are perceived to be essentially unspiritual. What can be anti-intellectualism regards as a higher form of knowledge that which cannot be known by natural understanding, since the Spirit goes beyond words. Pentecostals tend to major repeatedly on central home-grown themes within the movement, and as a result omitting massive sections of Scripture and Biblical doctrine. Such gross imbalance is not helpful to Pentecostalism..

\section{Miracle crazed}

As a movement fuelled by an expectancy of God's constant supernatural demonstration of his power and presence, Pentecostals look to see God's activity in miracles and healings. Pentecostalism sets the supernatural over and against the natural. Without a solid doctrinal foundation of providence and the sovereignty of God over all things in creation, Pentecostals expect God's normal working in ways contrary to nature and common sense. There are clear warnings to any movement running after signs and wonders in the last days in the New Testament.

\section{Angelic engrossment}

An over-emphasis of demonic activity and reliance on spiritual warfare tends to create an unhealthy deliverance mentality within the Pentecostal circles, who can become obsessed with a fixation on angelic forces and the interpretation of end-time events, providing an enormous diversion from attention to growth in moral and spiritual maturity.

\section{Pentecostalism and Development in Africa}

"Pentecostalism in Africa has a new attraction for leadership, the mobile, the lay- people orientation leadership, ecclesiastical office based on the persons charismatic gifting, innovative use of modern media technologies".( Anderson, 1999:215) 
Pentecostal/ Charismatics have played both functional and dye-functional roles. Pastors from here serve as providers of supernatural protection for politicians, seeking to consolidate power by entrenching themselves in office. Politically corrupt office holders depend on charms from their shrines to keep themselves going. What people consider important in theology are the things that address their religious need. Pentecostals have proven successful in Africa because of its openness to the supernatural and through its interventionist and oral theological forms that resonate with traditional African Piety. The intention of the practitioners has always been to be Biblical, but in a real sense expresses something else. (Anderson, 1999; 215)

Pentecostalism which rose in the early $20^{\text {th }}$ century among the poor- socio- economic class, today has spread across the length and breath of the southern Hemisphere, and for Africa in the sub- Saharan area. Furthermore, this movement has become the fastest growing Christian movement world- wide. (Anderson 2004; 1, Burgess and Van der Maas, 2002)

By far the majority of the new Pentecostals and Charismatic converts are found in the Non- Western World, particularly in Latin America, Asia and Africa. (Barrett, 2001).

In the same vain, it is wordy to mention that the Mainline Christian Churches were at the fore front of developmental work in Africa for decades. Today they have different works through their agencies

It is a well-known fact that Pentecostals and charismatics are extremely effective in bringing about dramatic changes in any place of their operation. The Pentecostal that operate among traditional Africans that are engulfed in their usual traditional demand of helping less wealthy relatives while also contributing to the costly communed rituals and ceremonies, now receive economic indument for their Pentecostal pathners. Meanwhile, in no distant time the Africa believer become wealthy and his peers sooner or later begin to accuse him of witchcraft or sorecery.

Africa Pentecostals believe in hard work and deeply felt prayers. They strive for improvement and are ready to buy in anything new. Pentecostals are exceptionally effective at bringing about the type of change that is called "development". This is the key interlinked changes that is associated with the change that brought Pentecostals to the limelight

One of the most favourable strategy employed by the Pentecostals was the use of economical behavioural change against their perceived unwanted products like alcohol, cigarette, etc. Their clergy will try to stop them from buying these products, thereby making the seller to loss their customer.

The use of manipulative method is another option to enrich their church. The pastor would ask members to close their eyes while filling a blank cheque in their mind and they will in the nearest future receive their monetary request from God. Many have come forward to testify of how they have been blessed for obeying His words. (Meyer,1998b :762- 763)

Another issue of great importance is that of members being forced to open and running their own private businesses. According to them as an employee you'll never get rich (Fraston 1995: 132), hence they are encouraged to resign from their jobs. In addition to this, these clergy went on to offer their members training in business and management studies to give them a proper footing in the running of their businesses.. Van Dijk, 2012: 96 in his publication shows Pentecostal Pastors in Ghana and Botswana, devoting extensive time and energy to traine their members on how modern believers would be transformed and developed into a proactive and goal oriented agent. Most of these churches draw up their teachings from well- known Pentecostal Preachers like David Oyedipo's, book "Maximise Your Destiny", Michael Ntumy's Financial Break through and Discovering Gods Secrets to Prosperity. Truly speaking, Pentecostals are interested in seeing their followers become living testimonies to the surprise of everyone. They are proud of their members and are there to provide adequate help that can lead them to fulfillment in life and business.

\section{Conclusion:-}

The progress made by the Pentecostals at the expense of the mainline churches is attracting reactions that among them is; to imitate them, generally through their contextualized dances, preaching etc. These are regarded as major incideny that are used to influence them by the Pentecostals. 
Furthermore, the mainline Churches have gone into a comparative research to ascertain what they need to do to achieve a better result than the Pentecostals who are busy winning the members over to the Pentecostal circles. Also attempts are being made to supply those missing essentials in other to stop their followers from living them. Proliferation of churches in Nigeria is another evidence that boost the growth of Pentecostalism, hence the reason why Pentecostalism is now a major source of business entrepreneurship. It is rather unfortunate, that while the government is reluctant in addressing the poverty situation of her people, the Pentecostal/Charismatic churches have seen that as a loophole that they are utilizing to attract the poor ones to their churches, hence the poor ones are now the young bride that everyone is look out for..

\section{Recommendations}

The following recommendations are made to help address some of the problems encountered in the cause of writing the paper.

1. Pentecostal/ Charismatic Church activities should be encourage since a greater percentage of our people are the beneficiaries

2. Attention should be given for a better package entrepreneurship business plan for the benefit of the people irrespective of the Churches concern.

3. The mainline Churches should be encouraged to join hands in producing a well packaged contextualize hymns, etc. for the Church.

4. A further research should be carried out on how to improve on the general performance of Pentecostal/ Charismatic development for the good of the Body of Christ.

\section{Refrences:-}

1. Anderson, 1999 "Global Pentecostalism in the New Millennium; in Allan Anderson and Walter Hoolenweger, ed, Pentecostals after century: Global Perspective on a movement in Transition, Sheffield Academy Press.

2. Bruner, F. D,1970, A Theology of the Holy Spirit, Eerdmas, Grand Rapids.

3. Culpepper, R. H, 1977,Evaluating the Charismatic Movement: A Theological and Biblical Appraisal, Judson Press, Valley Forge.

4. Barrett, David B,1988 'Statistics, global', Stanley M Burgess \& Gary B McGee (eds),Dictionary of Pentecostal and Charismatic Movements (Grand Rapids: Zondervan).

5. Bowler, Kate (2013). Blessed: A History of the American Prosperity Gospel. Oxford University Press. ISBN 978-0199827695.

6. Burgess, Stanley and Eduard van der Maas (Eds). 2002. The New International Dictionary of Pentecostal and Charismatic Movements. Michigan: Zondervan.

7. Freston, Paul. 1995. Pentecostalism in Brazil: A Brief History. Religion, 25: 119-133.

8. Harvey G. Cox. 1996. Fire from Heaven: The Rise of Pentecostal Spirituality and the Reshaping of Religion in the Twenty-First Century. Reading, Massachusetts, USA: Addison-Wesley; "The Myth of the Twentieth Century: The Rise and Fall of Secularization.” 1999. In Harvard Divinity Bulletin, Vol. 28, 2/3, 6-8

9. Lee, S, Y., 2001, Grace and Power in Pentecostal and Charismatic Theology, Theologistic Universiteit Van Apddoorn .

10. Meyer, Birgit. 1998b. Commodities and the Power of Prayer: Pentecostalist Attitudes towards Consumption in Contemporary Ghana. Development and Change, 29: 751-776.

11. Moller, F. P., 1983, Die Diskussie oor die Charismata Soos Wat dit in die Pinksterbeweging geleer en beoefen Word, Evangelie Uitgewers, Braafontein, 23

12. Paker, J. I (1984), Keep in Step with the Spirit, IVP.

13. Tomalin, Emma,(ed) 2015, The Routledge Hand book of Religious and Global Development, Abingdon, Oxford, UK- (Article- Jan, 2008) www.http//epriints:/se.ac.uk/67826

14. Robbins, Joel (2010). Allan Anderson (ed.). Studying Global Pentecostalism: Theories and Methods. Michael Bergunder, André Droogers, and Cornelis van der Laan. University of California Press. ISBN 978-0-52026662-9.

15. Ukah, A., 2007, African Christianities; Features, Promises and Problems, Johannes Gutenberg- Universitat, Germany. PMid:18390067.

16. Van Dijk, Rijk. 2012. Pentecostalism and Post-Development: Exploring Religion as a Developmental Ideology in Ghanaian Migrant Communities. In Freeman, Dena (Ed). Pentecostalism and Development: Churches, NGOs and Social Change in Africa. London: Palgrave Macmillan.

17. Walton, Jonathan L. (2009). Watch This! The Ethics and Aesthetics of Black Televangelism. NYU Press. ISBN 978-0-8147-9417-3. 
18. Wilson, J. Matthew (2007). From Pews to Polling Places: Faith and Politics in the American Religious Mosaic. Georgetown University Press. ISBN 978-1-58901-172-4.

19. Williams, J. R. 2005a, Charismatic Movement: Advanced Information, Viewed 01 February, 2010, http//www.mb-soff.com

20. Williams, J.R., 2005b, The Charismatic Movement and reformed Theology, Viewed 01 February, 2010 from http//home.regent.edu/rodnw.1/tpo7.html. 